していただくこと，そして従来型立位撮影台MSミクロリーダーの 基本設計理念である電気回路を一切組み込まないですべてマニュア ル操作で最大の作業性・便宜性・そして安全性を確保することを踏 蛽し、さらに，性能向上のための開発を行った。

\section{0 座位式撮影用電動椅子について}

\section{福岡放射線株式会社 畠山重幸}

立位撮影台において，通常の立位撮影の他に必要に応じ，装置を 簡単に引き出して、䫓椎、腰椎の座位撮影が容易にできる電動椅子 を製作した。この装置は上下 $200 \mathrm{~mm}$ (床上 $520 \mathrm{~mm} \sim 720 \mathrm{~mm}$ )， 前後 $200 \mathrm{~mm}$ ，左右 $1150 \mathrm{~mm}$ ，正面を見た状態から左右に $\pm 90^{\circ}$ 回転させることができる。そその他，アームレスト(腕のせ)が退避可 能で、背もたれが着脱できる. 䁰椎の斜位撮影時は、椅子の回転を 使い、所定の角度に設定して使用する。

\section{1 迅速現像処理におけるレギュラーフィルムの物理的検討} 順天堂大学医学部附属順天堂医院 堂領和彦, 他 6 名 【目的】45秒処理対応のRX-Uについて自現機の処理時間，温度変化 での物理的検討，および従来のRXとの比較も行ったので報告す る.

【方法】RX-Uを45、90秒，RXを90秒処理で温度を変化させ試料を 作成し、物理的評価を求めた。

【結果】両者とも温度上昇により感度は高くなり，RX-Uの方が変化 の割合は少ないものの平均階調度も高くなった，MTFは，両者と も温度変化で影響はみられず，RMSは，両者とも温度上昇に伴い 悪くなるが，RX-Uの方が変化の割合は少なかった。また，RX-U は処理時間が異なっても、システム感度が同一であればほぼ同じ物 理的評価が得られた。

【結論】RX-Uは、45秒処理でも従来とほぼ同等である。

\section{2 ボケの視覚評価}

\section{杏林大学医学部付属病院 高橋正勝，他 1 名}

物理的なボケとは別に，観察者がボケていると感じるには，個人 差があるように思う．ボケの視覚評価において、その個人差はどん な感覚の元に成り立っているのかを文献にもとつうき調べてみると、 実際に画像を観察する場合に，腹部CT撮影と言われると，まず腹 部C丁の画像が言語システムにより頭の中に準備され，撮影し表示 された画像を見て腹部CTの画像パターンとして知覚し、次に画像

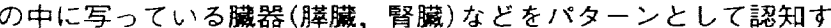
る. 認知された画像は複雑な臟器の構成によって起こり得る視覚的 錯覚，モニタによる明るさの変化，モニタ上に写るスケールや文字 による影響を受けながら，画像を観察すると考えられる。

13 カセッテ専用普及型CR装置FCR3000の有用性について 東京慈恵会医科大学付属第三病院 高下マリ，他 7 名

当院のような技師の人数に制限のある施設では，暗室作業などが 煩わしく、FCR30000導入に伴い4 個のカセッテスタッカによる カセッテ連続処理が可能になり人員的労力が減った。 また撮影室単 位で1Dターミナルを設置することで効率よいD登録ができ，その うえ画像モニタ上で再撮の確認ができることで時間的口スも減っ た。また普及タイプのFCRなので省スペース設計で，スペースに問 題のある当院においても作業効率のよい配置が可能となった。シス テムの拡張性も，施設の規模に応じてシステムアップできる点は当 院にとって効率的で，なおかつ有用であると思わ机る。

14 最新のディジタル超音波カラードプラ装置のBモード分解 能およびドプラモードスライス幅についての検討 東京慈恵会医科大学付属第三病院 熊谷史範，他 7 名

今回われわれは，最新のディジタル超音波カラードプラ装置最高 機種について，その基本性能を把握，分析する機会を得たので報告 する．最小 $200 \mu \mathrm{m}$ まで測定可能なターゲットファントムを使用 し、Bモードにおける距離方向および方位方向の分解能の計測。ま た、最小 $1 \mathrm{~mm}$ まで測定可能なドプラフローファントムを使用し， カラードプラモードおよびFFT計測モードにおけるスライス幅の計 測を行った。最も良い分解能を持つ装置では，距離方向および方位 方向ともに最小 $200 \mu \mathrm{m}$ であり、またカラードプラモードおよび FFT計測モ一ドにおけるスライス幅は，最も良い装置で水深 $2 \mathrm{~cm} の$ 深さで最小 $3 \mathrm{~mm}$ の結果を得た。

\section{一般研究発表 2 \\ 的部撮影・楾量淜定}

座長 日本大学医学部付属練馬光が丘病院 佐藤幸光

越沼，伊藤ら(東京都立医癔技術短大)は，それぞれ「胸部撮影に おける障害陰影因子一衣服におけるアンケート調査結果，一胸部撮 影用検査衣の試作一」のテーマについて，衣類，毛髮等によるアー チファクトが画像上の障害陰影をもたらす影響について，CRとF S系で検討した，CR系の方がF/S系に比べて，綿，ポリエステルな どの素材でも描出した。その対策として演者らは，紙製の検査衣を 試作して改善を試みた。羽部(駒澤短大)らは，「診断用X線領域に おける蛍光ガラス線量計の基礎特性」のテーマについて，素子間の ばらつき、線量依存性、エネルギー特性などを用いて評価し、診断 用X線領域において，蛍光ガラス線量計の適用の有無について検討 した，坂野(駒澤短大専攻科)らは，「CdTe半導体検出器によるX線 スペクトル測定」のテーマについて，基本特性とスペクトル補正法 からX線の線質測定の適用の有無について検討を加えた。

\section{5 胸部X線撮影における障害陰影因子の検討一衣服に関する アンケート調查結果一}

東京都立医療技術短期大学 越沼沙織，他 7 名

今回，われわれは胸部撮影に限定し、衣類などによる障害陰影の 影響についての検討を行った．実験を行う前に，実際臨床の現場の 状況を把握するために衣服類 ( るトラブルなどのアンケート調查を各施設に依頼した．その結果を もとに，障害陰影を生じると回答のあった衣類など(プリント柄， 毛髪など)をF/SおよびCR系で再現した。この結果、プリント柄， 検查衣のしわ，たるみによる折りじわがF/SおよびCR系ともに障 害陰影として認められた。しかし，素材(綿，ポリエステル）、衣類 (Tシャツ，ゆかたなど)によりF/S系では認められないものもCR系 では認められた。

\section{6 眴部X線撮影における障害陰影因子の検討一胸部撮影用検 查衣の試作一}

東京都立医療技術短期大学 伊藤聖美，他 7名

衣服に関するアンケート調査結果より，F/S系で撮像されなかっ た布の検査衣がCRでは撮像されることが分かった。しかし，ディ スポーザブル用の紙製の検查衣は写真に撮像されなかったことが確 認された．以上より，紙製の検査衣を着衣させるのが望ましいと思 われる，そこで，患者のプライバシーを尊重した紙製の検査衣を製 作した。その結果，障害陰影はほとんど認められず、かつ容易に製 作でき，廉価という利点を有している。

\section{7 診断用X線領域における蛍光ガラス線堛計の基礎特性}

駒澤短期大学 羽部正徳，他 3 名

X線診断領域において，医癔被曝を低隇するためには，患者被曝 の測定が必要である. そこで，表面の吸収線量や実効エネルギーが 容易に得られることから、蛍光ガラス線量計に着目した。今回は, 表面の吸収線量を求めるにあたり，基礎特性として，ビルドアップ の温度依存性、表面の吸収線量の直線性, 管電圧と実効エネルギー について実験を行い，X線診断領域における使用限界があることが 確認できた。また，測定結果から，管電圧と実効エネルギー，表面 の吸収線量の関係をノモグラフに示すことで，X線撮影条件の表面 の吸收線量を容易に求めることができた。これらのことから，蛍光 ガラス線量計がX線診断領域において有用であることが確認でき た。

\section{$18 \mathrm{CdTe}$ 半導体検出器によるX線スペクトル測定} 駒澤短期大学 坂野智一, 他 2 名

$\mathrm{CdTe}$ 半導体検出器ではスペクトルがコンプトンやKエスケープ により変形される. stripping法を用いてスペクトルを補正し，線 質の視党的評価と定量的評価を行った。一般的に線質は実効エネル ギーで表すが，容易に算出できる平均エネルギーで線質を表した。 また，線質指標のように，平均エネルギー/管電圧を用いて線質を 評価した．管電圧とフィルタの変化について線質評価を行ったとこ ろ、管電圧が低いほど単一エネルギーに近い分布を示し、フィルタ の|//。が小さいほど単一エネルギーに近い分布を示した。このよう に，平均エネルギーを用いて定量的に線質を評価でき，スペクトル から視覚的にも評価できることを確認した。 